\title{
IMPROVING STUDENTS' VOCABULARY MASTERY THROUGH CONTEXT CLUES IN UNDERSTANDING READING TEXTS BY USING GOOGLE CLASSROOM AT GRADE XII MS 2 SMA NEGERI PLUS RIAU
}

\author{
Tengku Emadesti \\ SMA Negeri PLUS, Pekanbaru, Indonesia \\ emadestitengku@gmail.com
}

\begin{abstract}
The purpose of this article was to explain the effect of context clues to improve students' vocabulary mastery in understanding reading texts by using google classroom at grade XII MS 2 SMAN Plus Riau and factors influenced the improvement. Data were collected through checklist formats, field notes, and tests. This classroom action research was conducted in two cycles constituting 3 meetings for each cycle. The result of this research revealed that the students' vocabulary mastery in understanding reading texts by using google classroom increased in each cycle. In the first cycle, the percentage of students' vocabulary mastery was $80.60 \%$. However, this result was not satisfactory yet. Thus, the research was continued to cycle II. In the second cycle, the increase of students' vocabulary mastery was $90.08 \%$. This implied that there is an increase of students' vocabulary mastery in understanding reading texts by using google classroom in second cycles. In conclusion, the use of context clues increased the students' vocabulary mastery in understanding reading texts by using google classroom.
\end{abstract}

Keywords: vocabulary mastery, context clues, google classroom

\section{MENINGKATKAN PENGUASAAN KOSAKATA SISWA MELALUI CONTEXT CLUES UNTUK MEMAHAMI WACANA DENGAN MENGGUNAKAN MEDIA GOOGLE CLASSROOM DI KELAS XII MS 2 SMA NEGERI PLUS PROVINSI RIAU}

\begin{abstract}
ABSTRAK
Penelitian ini bertujuan untuk mengetahui apakah context clues memberikan peningkatan terhadap penguasaaan kosakata siswa untuk memahami wacana berbantuan aplikasi google classroom di kelas XII MS 2 SMA Negeri Plus Provinsi Riau beserta factor yang mempengaruhinya. Tetapi dalam penelitian ini dilaksanakan di kelas XII MS 2 SMA Negeri Plus Provinsi Riau dengan mengumpulkan data, lembaran observasi, catatan lapangan, dan ujian tertulis. Penelitian tindakan kelas ini terdiri dari dua siklus sebanyak 3 kali pertemuan untuk setiap siklus. Hasil penelitian ini menunjukkan penguasaaan kosakata siswa untuk memahami wacana berbantuan aplikasi google classroom meningkat pada setiap siklusnya. Pada siklus pertama, persentase siswa terhadap penguasaaan kosakata berbantuan aplikasi google classroom sebanyak $80.60 \%$. Namun, hasil ini dirasa belum memuaskan. Pada siklus kedua, pengingkatan penguasaaan kosakata berbantuan aplikasi google classroom adalah $90.08 \%$. Artinya bahwa ada peningkatan penguasaan kosakata untuk memahami wacana berbantuan aplikasi goggle classroom di siklus kedua. Kesimpulannya, penggunaan Context clues dapat meningkatkan penguasaaan kosakata siswa untuk memahami wacana dengan menggunakan media google classroom.
\end{abstract}

Kata Kunci: penguasaan kosakata, context clues, google classroom

\begin{tabular}{|c|c|c|}
\hline Submitted & Accepted & Published \\
\hline 07 November 2020 & 16 Januari 2021 & 26 Januari 2021 \\
\hline
\end{tabular}

\begin{tabular}{|l|c|c|}
\hline Citation & $:$ & $\begin{array}{c}\text { Emadesti, T. (2020). Improving Students' Vocabulary Mastery through Context Clues in Understanding Reading Texts } \\
\text { by Using Google Classroom at Grade XII MS 2 SMA Negeri Plus Riau. Jurnal PAJAR (Pendidikan dan } \\
\text { Pengajaran), 5(1), 111-120. DOI : } \underline{\text { http://dx.doi.org/10.33578/pjr.v5i1.8207. }}\end{array}$ \\
\hline
\end{tabular}

\section{INTRODUCTION}

Reading is to obtain and convey the information or messages stated in the reading texts using vocabulary items. Vocabularies affect not only the students' reading skills, but also their speaking, listening, and writing skills. Even though students realize the importance of vocabulary when learning language, most Vietnamese students learn vocabulary passively due to several factors. First, they consider the teacher's explanation for meaning or definition, 
pronunciation, spelling and grammatical functions boring ( Huyen and Nga, 2003). In a very real sense, the teachers use the traditional and monotonous teaching techniques which not involving the students communicatively, just ask students to read, find difficult words by looking them a dictionary, and ask them to answer the questions. They are often served with the same techniques in the learning process almost all of the time. It makes the students get bored and reluctant to be involved actively in understanding reading texts. And also they not have enough time in teaching learning process. It mean it is needed a technology to help them to study whenever and everywhere. That is by using Google Classroom application . it is a tool which facilitates students and teacher collaboration; also teacher can create and distribute assignments for students in an online classroom for free. It also has some benefits such as paperless, can be accessed anywhere and everywhere as long as there is internet connection and from any devices, to communicate between teachers and students, to give feedback to students, and personalized learning.

All of these facts brought about an assumption that the teaching of reading at SMA Negeri Plus of Riau Province needs improvement. To be more specific, it was essential that teachers, including the researcher, need to get introduced to a new way in teaching reading and then apply it in the teaching and learning process. The word 'new' here does not necessarily mean that it is up to date or current. As long as the teachers never utilize the way, it could also be categorized as 'new.' The new way that at last comes into the researchers' mind is the use of Google Classroom application in teaching Reading texts. Allen (1983:3) proposes two factors that will affect the failure of students in understanding the meaning of words. Those are: (1) they do not have any skills in comprehending the meaning of words, and (2) they do not have enough basic competencies to translate both words and sentences in a text. Therefore, to know the meaning of the words in the sentences, it is important that the students be provided with techniques or ways for inferring the meanings of the unknown vocabularies. One of the techniques in learning reading skills is through context clues.

Therefore, when we just have a little vocabulary mastery, of course will be directly proportional to the mastery of context clues (Uzer, 2019). Context clues are only one of a variety of strategies that are suggested to use by the teachers in teaching vocabulary mastery. The first is learning vocabulary through creativities. The activity is a technique to help the students learn vocabulary items by using pictures as a media of teaching. The second is learning vocabulary items through guessing. This is a kind of teaching and learning the meaning of vocabulary items in contexts which needs a special approach in understanding sentences. The third is learning vocabulary items through definitions. This is useful in guiding students to define the meaning of words and to arrange them into correct phrases, clauses and sentences. The last is learning vocabularies through context clues. This is the way by which the students are trained to guess the meaning of a word through the surrounding words in contexts including activating their background knowledge from the topic of a text. Brown (1994:308) holds that providing contexts is a good strategy in guessing the meaning of difficult words. He further points out that the context is the word and the sentences surrounding particular words. He also argues that guessing will be accurate enough for learners to understand the authors' ideas. So, guessing a word from the context is very strategic and therefore it may be a helpful strategy for helping the students in understanding reading texts. However, the English teachers at SMAN Plus of Riau Province have not been familiar with teaching vocabulary mastery in understanding reading text through context clues, because this way of learning vocabulary mastery in understanding reading texts is not recommended in the curriculum of SMA. Therefore, the students of the Grade XII MS 2 of SMAN Plus of Riau Province have not been familiar with this technique.

Understanding the context can be very helpful for the students to help the students to understand reading texts. The context can be 
identified through some clue words, such as: "but" for contrasting ideas, "because" for cause and effect ideas, "so" for result ideas, etc. Based on the clued words, the students would be able to identify the context directly. And then, when they understand the context, they are likely to be able to guess the meaning of the difficult words, leading the students to catch the ideas, news, or information from the context.

Several researches have conducted by previous researchers on the context clues. The earlier findings about the context clues was from Johnson \& Baumann (1984) who found the use of meanings or context clues to help students identify words and that instruction can help improve their use of such clues. While Bukhori (2007) at English Department of UIN Suska Riau found that there is a significant contribution both to the understanding of context clues and punctuations to reading skills. It means that the students' reading skills can be predicted through the understandings both of the context clues and punctuations.

Although a lot of researches have been done on context clues, there is little information available on the use of context clues in improving vocabulary mastery in understanding a reading text by using google classroom application. In other words, it is worth studying on the use of context clues to improve vocabulary mastery in understanding a reading text by using google classroom application.

Context clues can theoretically improve students' vocabulary mastery. Therefore, it is important to conduct this study which explained the implementation of context clues by using google classroom application. This study aims whether context clues by using google classroom was presumed could better improve the students' vocabulary mastery at grade XII MS 1 of SMA Negeri Plus of Riau Province and to explain what factors that change it.

\section{LITERATURE REVIEW}

\section{Vocabulary Mastery}

Vocabulary is one of the English language components which are important to acquire clear meanings. In addittion, Marksheffel
(1966:236) defines vocabulary mastery as the ability to give meanings to the words. It is also proposed by Khatibs $(1987: 10)$ that vocabulary mastery refers to the ability to recognize the sounds and meaning of words as they appear in the written or printed symbols. Kustaryos' idea is different from their ideas who views vocabulary mastery as the ability to use the words in the appropriate context of use (Kustaryo, 1988:19). These opinions lead to the conclusion that the vocabulary mastery is the ability to give meaning to a number of words, to recognize the sound and meaning of the words that appear in the written material, and use those words in the appropriate context.

In summary, vocabulary is the total number of the words which establish a language that has lexical meaning and contextual meaning, while vocabulary mastery is the ability to give meaning to a number of words and to recognize the sound of words that appear in written material that has lexical meaning and contextual meaning. They can be grouped into general vocabulary, synonyms, antonyms, and changing of words. All of them are as indicators of this research. The statement above shows that the mastery of vocabulary is very important because it will influence the students' speaking, reading, writing, and listening skills. And for this reason, the teacher needs some ways to present vocabulary to the students in order to increase their vocabulary.

\section{Context Clues}

Context clues can be regarded as a working factor in the way that a learner comprehends a reading passage and context clues can greatly influences reading comprehension of EFL learners (Seyed jalal abdolmanafi roknii and hamid reza niknaqsh, 2013). Brown (1994:308) identifies that a context is a good strategy in guessing the meaning of difficulties words. He further points out that context is the word and sentences surrounding a particular words. He also argues that based on the context, guessing will be accurate enough for learners to the understanding of the author's ideas. So, making guessing from the context is very necessary when reading activities are done. This idea is supported by Joffe (1997) who confirms that context clues are hints 
that an author gives to help define difficult or unusual words. The clue may appear within the same sentences as the word refers, or it may be in a preceding or subsequent sentences. In other words, those context clues are signs, which can help the reader to know the meaning from the unknown words in a context. Brown's idea and Joffe's idea are very similar in its general outlines. They explain that context clues is a good strategy in guessing the meaning of a word and it can help the reader to know the meaning. Based on the statement above, a context clues is a way or a technique to determine the meaning of unfamiliar word, which develops students' vocabulary and reading comprehension.

\section{a. Definition and Types of Context Clues}

Ying (2005) defines a context clues as an effective approach to increase the vocabulary and reading comprehension, because it can help students infer the meaning of a new word.

\section{b. The Types of Context Clues}

Wassman and Rinsky (2000:39) classify context clues into two types, which are useful in understanding unknown words: (1) a semantic clue provides "meaning" information about unknown words, (2) a syntactic clue provides grammatical information about unknown words, indicating whether it is a noun, a verb, an adjective, or an adverb.

\section{c. Kinds of Context Clues}

McWorther (1996:4) divides context clues into four kinds: (a) definitions, (b) examples, (c) contrasts, and (d) inferences. But, Ying (2005) divides context clues into 11 kinds, (1) morphology, (2) reference words, (3) synonyms and antonyms, (4) hyponyms, (5) definitions, (6) alternatives, (7) restatements, (8) examples, (9) summary, (10) comparisons and contrasts, (11) punctuations. But Zainil (2006: 59) proposes seven kinds, which are: (a) definitions, (b) examples, (c) causes and effects, (d) contrasts, (e) restatements, (f) modifiers, (g) inferences/general contexts clues/sentences or paragraphs. The followings are the explanation of each of them as explained by Zainil, McWorther, and Ying.

\section{1) Definition or Direct Explanation}

It explains words directly by giving synonym-other words with similar meaning; others tell the meaning of words by using signal words such as that is, is a (the), is defined as, are, was, were, namely, means, refers to, can be called and in other words.

For example: Induction refers to the process of reasoning from the known to unknown.

\section{2) Example}

Examples are sometimes used to point out instances, characteristics, or incidents that illustrate the meaning of a word. The signal are like, for instance, such as, include, and for example.

For example: Most condiments such as pepper, mustard, and catch up are used to improve the flavor of foods.

\section{3) Contrast}

It is phrases or word that indicate opposite meanings.

For example: the woman's parents thwarted her marriage plans but encouraged her to leave home.

\section{4) Inference/General Context Clues/Sentence or Paragraph}

The reader must look for clues within, before, and after the sentence in which the word is used.

For example: At six on faster morning the bell in the church began it sonorous ring. The fool, deep, rich ring, of the bell could be heard in empty street as the sung come up.

\section{5) Cause and Effect}

One part of a sentence is a cause and another part is an effect of the cause. The words such as because, so due to, as a result indicate cause and effect relationships.

For example: Merry's eyes had been sore for almost a week, so her mother decided to take her to an oculist for a treatment.

\section{6) Restatement}

It is usually used to signal the familiar words or expression with the unfamiliar or difficult words. The words such as or, in other words, commas, parentheses, dashes, that is, etc.

For example: Students memorize information; in other word they learn and the remember basic rules and facts. 
According to Ying (2005), there are a number of different context clues that can help a reader infer the meaning of a new word. There are: 1) Morphology, the students can derive word meanings by examining internal, morphological features, like prefixes, suffixes, and root words. 2) Reference words, identifying the referents of pronouns may provide a clue to the meaning of an unfamiliar word. Example: Malnutrition gave him the shallowest of chests and thinnest of limbs. It stunted his growth. In this sentence, the effect of malnutrition is obvious. Students should be able to guess what malnutrition could have done to growth. Cohesion, Sometimes words in the same sentences or in adjacent sentences give an indication of the meaning of an unfamiliar word, because these words regularly co-occur with the unfamiliar word, producing what has been termed "collocational cohesion" (Halliday and Hasan 1976:287). 3) Synonyms and Antonyms Often the reader can find the meaning of new items in the same sentence. Example: We had never seen such a large cave: it was simply enormous. Obviously, the unknown word is a synonym for large. Example: To be pretty and not plain, affluent and not poor, represents status in certain social groups. We note that pretty and plain are opposites. When we see the next pair of words in a parallel construction, we can assume that affluent is the opposite of poor, and must therefore mean rich. 4) Hyponyms, very often the reader can see that the relationship between an unfamiliar word and a familiar word is that of a general concept accompanied by a specific example (a hyponym). Example: The museum contained almost every type of vehicle: cars, buses, trains, and even old carriages and coaches. Vehicle is being used as a hyponym; it encompasses all of the other items which are listed. Also, all of the listed items are of the same category. 5) Definitions, sometimes the writer defines the meaning of the word right in the text. Example: Many animals live only by killing other animals and eating them. They are called predatory animals. 6) Alternatives, the writer may give an alternative of an unfamiliar word to make the meaning known. Example:
Ichthyologists, or specialists in the study of fish, have contributed to our understanding of the past. The word "ichthyologist" is unfamiliar to some readers, but the writer explains the meaning by giving a more familiar term. 7) Restatement, often the writer gives enough explanation for the meaning to be clear. Example : $X$ ray therapy, that is, treatment by use of $X$ ray, often stops the growth of a tumor. The phrase that is signals a clarification of a previously used word. 8) Example, many times an author helps the reader get the meaning of a word by providing examples that illustrate the use of the word. Example: All the furniture had been completely removed so that not a single table or chair was to be seen. The learner should be able to guess the meaning of furniture from the two examples which are mentioned. 9) Summary, a summary clue sums up a situation or an idea with a word or a phrase. Example: Mrs. Christopher contributes money to the Red Cross, the Girls Club, and the Cancer Society. She also volunteers many hours in the emergency ward of the hospital. She is indeed altruistic. From the account of Mrs. Christopher's deeds, the reader can infer that "altruistic" means "unselfish". 10) Comparison and contrast Writers can show similarity or difference meanings. Example: The ancient mammoth, like other elephants, is huge. This sentence indicates similarity and clearly states that the ancient mammoth is a type of elephant. 11) Punctuation, readers can also use clues of punctuation and type style to infer meaning, such as quotation marks (showing the word has a special meaning), dashes (showing apposition), parentheses or brackets (enclosing a definition), and italics (showing the word will be defined).

Therefore, in using context clues to improve students' reading skills in understanding reading texts, it is important to avoid the wasting time for a useless activity in the classroom. The indicators are appropriate with the condition of students and curriculum of improving vocabulary reading skills through context clues in action are as follows:(a) definitions,(b) examples, (c) contrasts/antonyms, and (d) inferences.

The theory of McWorther is used as the indicators because these indicators are appropriate 
with the curriculum of grade XII MS 4, SMAN Plus of Riau Province in this semester.

\section{Google Classroom Application}

Google Classroom is a tool which facilitates students and teacher collaboration; also teacher can create and distribute assignments for students in an online classroom for free (Beal, 2017). It makes teachers simply build groups to share assignments and announcements. Google Classroom can be a tool that makes learners become active participants. Nagele (2017) said, teachers can create active lessons which are student-centered, collaborative, and unforgettable just through Google Classroom, because it provides easy-to-use learning features with students of all categories able to cooperate. Google Classroom is helpful to all of learner categories and including adult learners. It also has some benefits such as paperless, can be accessed anywhere and everywhere as long as there is internet connection and from any devices, to communicate between teachers and students, to give feedback to students, and personalized learning. It has a learning feature that makes teachers create and handle assignments actively and also provide feedback to students. In conclusion, Google Classroom makes it easier for teachers to handle students work. It is really beneficial for both teachers and students, because it is easy and simple to use, learning process can be effective and efficient because students and teachers can access Google Classroom anytime and anywhere in electronic devices with internet network

\section{RESEARCH METHODS}

This study was conducted through a classroom action research (Kemmis and Mc.Taggart, 1982:12). The action research in the language classroom is a tool for teacher and curriculum development to improve the way of teaching. It can be concluded that classroom action research tires to make solution in the classroom toward the problems that have been faced by the teachers at their subject areas. The data were collected by direct observations, field notes, and giving reading test. The participants of this study were 25 students of grade XII MS 2 of SMA Negeri of Plus of Riau Province in 2018/2019 academic year. The main instruments for the data collections were direct observations, field notes, and giving reading test. The next step after data collection were analyzed with qualitative and quantitative forms. Qualitative data were analyzed by data managing, reading or memoing, describing, classifying, interpreting. Quantitative data were analyzed by percentage (score of reading skills), Matrix and graph.

(a) Score of reading skills

\section{Score : correct answer $\times 100$ total items}

Percentage

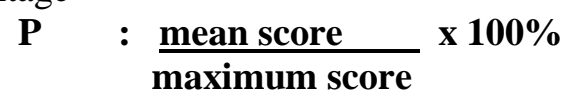

The categories are as follows:

$90-100 \%=$ excellent

$75-89 \%=$ good

$65-74 \%=$ fairy good

$55-64 \%$ = fair

$05-54 \%=$ poor

(Sudjana, $1986: 38$ )

The activities of the research used the following procedure:

1. Preparing reading texts by using google classroom application used to apply context clues (definitions, examples, contrasts/antonyms, synonyms).

2. Designing activities performed to apply context clues to improve their vocabulary mastery in understanding reading texts by using google classroom application.

The activities were planned as follows:

\section{The First Cycle}

a. Plans

In this cycle, it was planned and designed the activities in which the context clues were used to improve the students' vocabulary mastery by using google classroom application during the first cycle. The first cycle was done for three meetings The teaching schedules of the English teacher was one a week, Wednesday based on the academic calendar of the school conducted on 
August $7^{\text {th }}$ until $21^{\text {th }} 2019$. Finally, the researcher gave them tests.

\section{b. Actions}

After motivating and stimulating the students' prior knowledge in which the teacher asked the students about the technique that they used to know the meaning of the sentences in understanding the reading texts. These techniques were explained carefully and slowly. Then, the teacher asked the students to apply punctuations to overcome the problems. Finally in the post activities, the teacher concluded the lesson.

In the second meeting, In the whilst activities, she explained to the students how to use and understand the vocabularies by using punctuations. Finally in the post activities, the teacher concluded the lesson.

In the third meeting, the teacher did the same action as the second meeting. she asked them to guess the meaning of the words and the sentences in the reading texts by solving the punctuations. Finally in the post activities, the teacher concluded the lesson.

\section{c. Observations}

In analyzing the result of collaborator's observations on activities which showed students' reading skills and teacher's activities and the implementing of punctuations in the class in each cycle, the researcher used matrix table.

\section{d. Reflections or evaluations}

In this stage, the researcher collected the data by distributing reading tests to the students.
To measure students' reading skills for each indicator (two items for each indicator). The tests was given to the students and then the results were analyzed and evaluated to know the students success in the learning process in the first cycle to create the next plan for the next cycles. If the students did not achieve what it was hoped, it continues to the next cycles.

\section{The Second Cycle \\ a. Plans}

In cycle 2 , the activities were similar to those in cycle 1 . The differences were stressing on the revised plan. In the other words, in teaching learning process focused on what problem was unsolved in the revised plan cycle 1 . The cycle was done for three meetings. The first meeting was done on August $28^{\text {th }}$, the second meeting was done on September $4^{\text {th }}$ and the last meeting was done on $11^{\text {th }}$ of September 2019. The time for each meeting was 90 minutes (2x45 minutes). This collaborative action research consist of two cycles.

\section{RESULTS AND DISCUSSION}

This study based on the observation in the two cycles that were held for 6 meetings, It was found that the implementation of the context clues could be identified from the increasing number of the students' vocabulary mastery from cycle to cycle. The progression of each cycle could be seen in following table:

Table 1. The Progression of Students' Vocabulary Mastery in Understanding Reading Texts by Using Google Classroom Application

\begin{tabular}{ccc}
\hline No & Cycles & Students' Vocabulary Mastery \\
\hline 1 & Before Context Clues & $70.20 \%$ \\
2 & First cycle & $80.60 \%$ \\
3 & Second cycle & $90.08 \%$ \\
\hline
\end{tabular}

On cycle 1 , the average score was $80.60 \%$. there were 2 students got excellent, 20 students got good and 2 students got fairy good. It means the increasing was about $10.40 \%$ It matched with Yings' research (2005). He found that context clues is effective approach to increase reading comprehension, because it can help students infer the meaning of a new words. 
It is supported a significant influence of context clues strategy on student reading narrative text achievement of the tenth grade students of state Senior High School 2 of Palembang (Uzer, 2019). Although there was increasing of students' vocabulary mastery in understanding the reading texts by using google classroom application at cycle I but it was not satisfied yet. There were still problems faced by the students. Firstly, the students still found difficulty to know the meaning of words and the sentences in understanding the reading texts because they have limited vocabulary mastery. Secondly, they were still doubt in identifying synonyms, antonyms/contrasts. There were $48 \%$ of students still categorized in low score. It means the second cycle needed to be continued.

In the second cycle the researcher focus on instruction in applying the context clues to students, then gave more time allocation in identifying on contrasts /antonyms and synonyms to overcome the problems. In this case the researcher emphasized the implementation contrasts, definitions and examples. The researcher redesigned some teaching activities. The average score was $90.08 \%$ there were 19 students got excellent and 6 students got good. It was supported by Brown (1994) who found a context is a good strategy in guessing the meaning of difficulties words. He further points out that context is the words and sentences surrounding a particular words. The result showed that $90.08 \%$ or 22 students got good score. It means the second cycle successfully increased the students' vocabulary mastery in understanding the reading texts by using google classroom application.

This study found that the implementation of the context clues could be identified from the increasing number of the students' vocabulary mastery by using google classroom application from cycle to cycle. It was supported by her collaborator's field notes. He noted that the students could answer the questions easily by using context clues without looking a dictionary. It means that they could improve their vocabulary mastery. It could be drawn as follows:

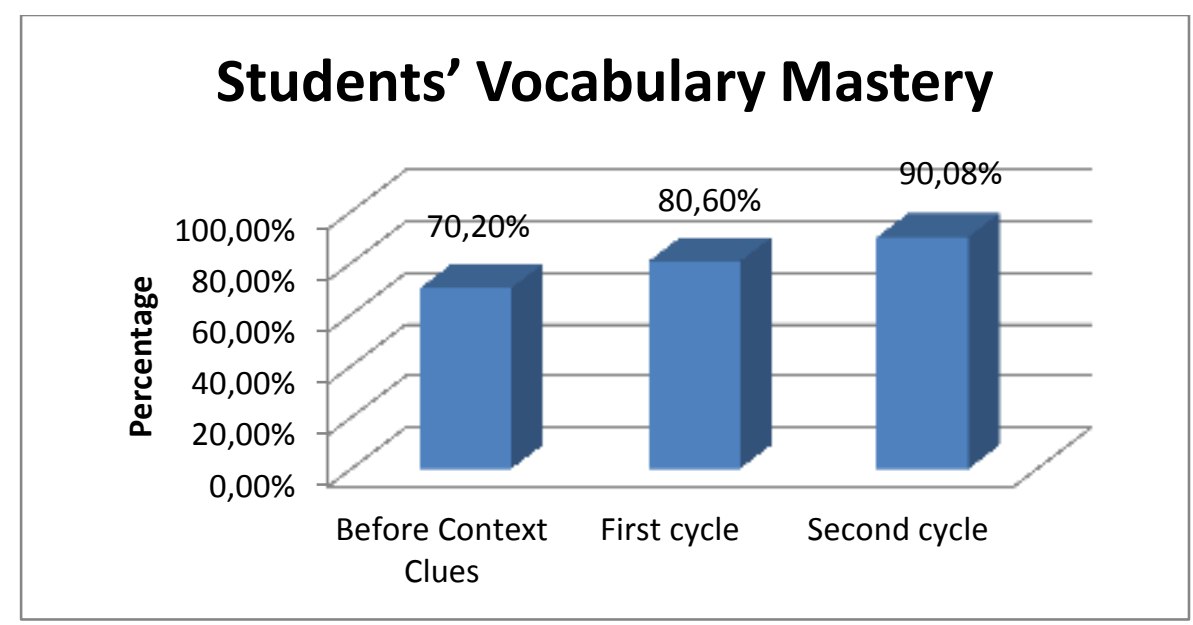

\section{Figure1. The Result of Vocabulary Mastery in Understanding the Reading Texts by Using Google Classroom Application}

In implementing the context clues, it could be identified some factors that influenced it. In the first cycle the factors are; first, time allocation in implementing context clues, second, students' understanding in implementing context clues, third, Classroom atmosphere. In the second cycle are: first, time allocation in implementing context clues, second, classroom atmosphere. 
In conclusion, the implementation of context clues gave positive effect toward the students' vocabulary mastery in understanding the reading texts by using google classroom application. There was 90.08 . \% or 22 students were categorized good score. In other words, the context clues can better increase or improve students' vocabulary mastery in understanding the reading texts by using google classroom application at grade XII MS 2 of SMAN Plus of Riau Province.

\section{CONCLUSIONS RECOMMENDATION}

AND

Based on the foregoing description and discussion, several conclusions are drawn as follows. First, punctuations better improve the students' reading skills by using google classroom application at grade XII MS 1 of SMA Negeri Plus of Riau Province. It means it can stimulate and increase the students' reading skills. Second, there were some factors that influence the changing of the students' reading skills by using google classroom application by implementing punctuations, namely;(a) time allocation in implementing of the punctuations.(b) students' understanding in implementing the punctuations in reading skills. (c) classroom atmosphere while the punctuations were implemented.

Based on the aforementioned conclusions, some recommendations are proposed as follows. First, it is suggested for the researcher as an English teacher to apply the punctuations in improving students' reading skills and to minimize the use of dictionary in understanding reading texts. Second, it is suggested to other researchers to investigate other strategies in helping students to increase reading skills because most of science and knowledge are obtained through reading skills.

\section{REFERENCES}

Allen, V. \& French. (1983). Techniques in Teaching Vocabulary. New York: Oxford University Press.
Beal, V. (2017). Google Classroom. Webopedia : http://www.webopedia.com/TERM/G/goo gle-classroom.html

Brown, G \& Yule, G. ( no year ). Discourse Analysis. Sydney: Cambridge University Press.

Brown. H. \& Doughlas. (1994). Teaching by Principles, An interactive Approach to Language Pedagogy. New Jersey: Prentice Hall Regents.

Bukhori. (2007). 'The Contribution of Understanding Context Clues and Punctuations toward Reading Skills at English Education Department of UIN Sultan Syarif Kasim Riau". Unpublished Thesis. Padang: Universitas Negeri Padang,

Hornby, A. S. (1987). Advanced learner's Dictionary of English Oxford: Oxford University Press.

Huyen, N. T. T., \& Nga, K.T,T. ( 2003) Learing Vocabulary through Games. Asean EFL Journal, $\quad$ https://asian-efljournal.com/dec_03_vn.pdf

Jalal A.S., \& Hamid, R.N. (2013). The Effect of Context Clues on EFL Learners' Reading Comprehension. India International Journal,

http://www.eltvoices.in/Volume3/Issue_6/ EVI 36 7.pdf

Joffe, \& Irwan L. (1997). "Opportunity for Successful Reading". $8^{\text {th }}$ ed. Belmot: Wadssworth. In College Reading Skills Program. (http://www.esupomona.edu/ /Ire/crsp/ha ndouts/context_clues.html.

Kemmis, S \& McTaggart, R. (1988). The Action Research Planner $\quad\left(3^{\text {rd }} e d\right)$. Victoria: Deakin University Press.

Khatib., \& Kharti, Y. (1987)." The Correlation between the Mastery Vocabulary and the Mastery of Reading Comprehension : A Case Study at the Two Year Diploma Program (D2) of English.Department of IKIP Padang". Research Report. Padang: FPBS IKIP Padang. 
Kustaryo, S. (1988). Reading Technique for College students. Jakarta: Depdikbud Dirjen Dikti PPLPTK.

Longman. (1987). Dictionary of Contemporary English. London: Pitman Press.

Marksheffel, Ned, D. (1966). Reading in Second Secondary School. New York: The Royal Press Company.

McWhorter, K. (1986). Guide to College Reading. Toronto: Little, Brown and Company.

Mills, G. E. (2000). Action Research: A Guide for the Teacher Researcher. New Jersey: Prentice-Hall, Inc.

Nunan, D. (1991). Language Teaching Methodology: A text book for teachers.London: Prentice Hall International.

Uzer, Y,V., (2019). The Influence of Context Clues Strategy on Students' Reading Achievement. Journal of English Study Programme. Vol 2, No 2 (2019). https://jurnal.univpgri-

palembang.ac.id/index.php/esteem/article/ view/2457/4298

Wassman, R., \& Lee, A. R. (2000). Effective Reading in Changing the World. Singapore: Pearson Asia Pte.Ltd.

Ying, S. Yu. (2005). “ Acquiring Vocabulary Through a Context-based Approach ". English Teaching Forum. Vol.39.

http://exchanges.state.gov/forum/vols/vol 39/no1/p18.htm\#top\#top

Young, R. M., \& Harriet, S. (1982). Better Learning. New Jersey: Prentice Hall, Inc.

Yusuf, Y. (1991). "Mengukur Pengetahuan Vocabulary Mahasiswa S1 Jurusan Pendidikan Bahasa Inggris FPBS IKIP Padang" Thesis FPBS IKIP Padang.

Zainil. (2006). Actional Functional Model (AFM): Teacher's Guide for Intermediate Students. Padang: University Negeri Padang Press.

Zainil. (2006). Actional Functional Model (AFM). Padang: Universitas Negeri Padang Press 